\title{
Innovative Teaching of Civil Engineering Materials
}

\author{
Yanqin Guo \\ School of Huanghe Science and Technology College, Zhengzhou 450063, China \\ 27669932@qq.com
}

Keywords: Teaching exploration; Module teaching; Teachers and students; Theoretical practice

\begin{abstract}
According to the characteristics of the course of civil engineering materials,this paper from three aspects of civil engineering materials innovation type teaching are explored: adoption of module teaching method teaching content; to the teaching method take the teachers and students were speaking class, theory and practice of inclusive classroom and new network classroom; diversified evaluation mode. Pay attention to cultivating students' creative thinking ability.
\end{abstract}

\section{Introduction}

In order to practice the Premier Li Keqiang's proposed "The mass innovation entrepreneurship" peoples' goals, Huanghe Science and Technology College founded "theYellow River public record space", the schools have worked a series of policies and measures to promote innovation and entrepreneurship, teachers and students are encouraged to participate in the innovation and entrepreneurship, in order to ensure innovation and entrepreneurship to work effectively, the school launched the reform of curriculum system for professional teachers teaching innovation in the course, the materials of civil engineering civil engineering as professional basic course, professional course of students first exposure to a connecting link between the preceding and the following in the construction of science. Learn the course well can not only provide the necessary professional basic knowledge for students following courses, also lays theoretical foundation for future engineering practice, at the same time, we must foster the students' experimental skill, it is the path to the professional courses, a new teaching of civil engineering materials is the basis for the students' professional knowledge innovation, is to lead the students to innovative learning the key. Innovative teaching of civil engineering materials is in the teaching content, teaching methods, the examination mode of innovation, To continuously explore and achieve the goal of cultivating innovative and highly qualified civil engineering personnel.

\section{Exploration}

\section{The innovation of teaching content}

Civil engineering materials Course need to learn more types of materials, more content, involving a wide range, strong practical, there is no necessary link between the material, their independence, the chapters are not closely linked, and the special terms of each material, basic feature, material selection method is also inconsistent, traditional teaching much to describe, analysis, induction and summary of materials, students' memory stronger ${ }^{[1]}$, Less computational theory, for the habit of logical operation and theoretical derivation, the space imagination and mathematical thinking ability of engineering students is lack of attraction, students generally feel boring, affect the students' learning motivation and learning interest. According to the characteristics of the course, the civil 
engineering materials course content of the block teaching innovation, the curriculum content is divided into four modules, As shown in Figure 1 below:

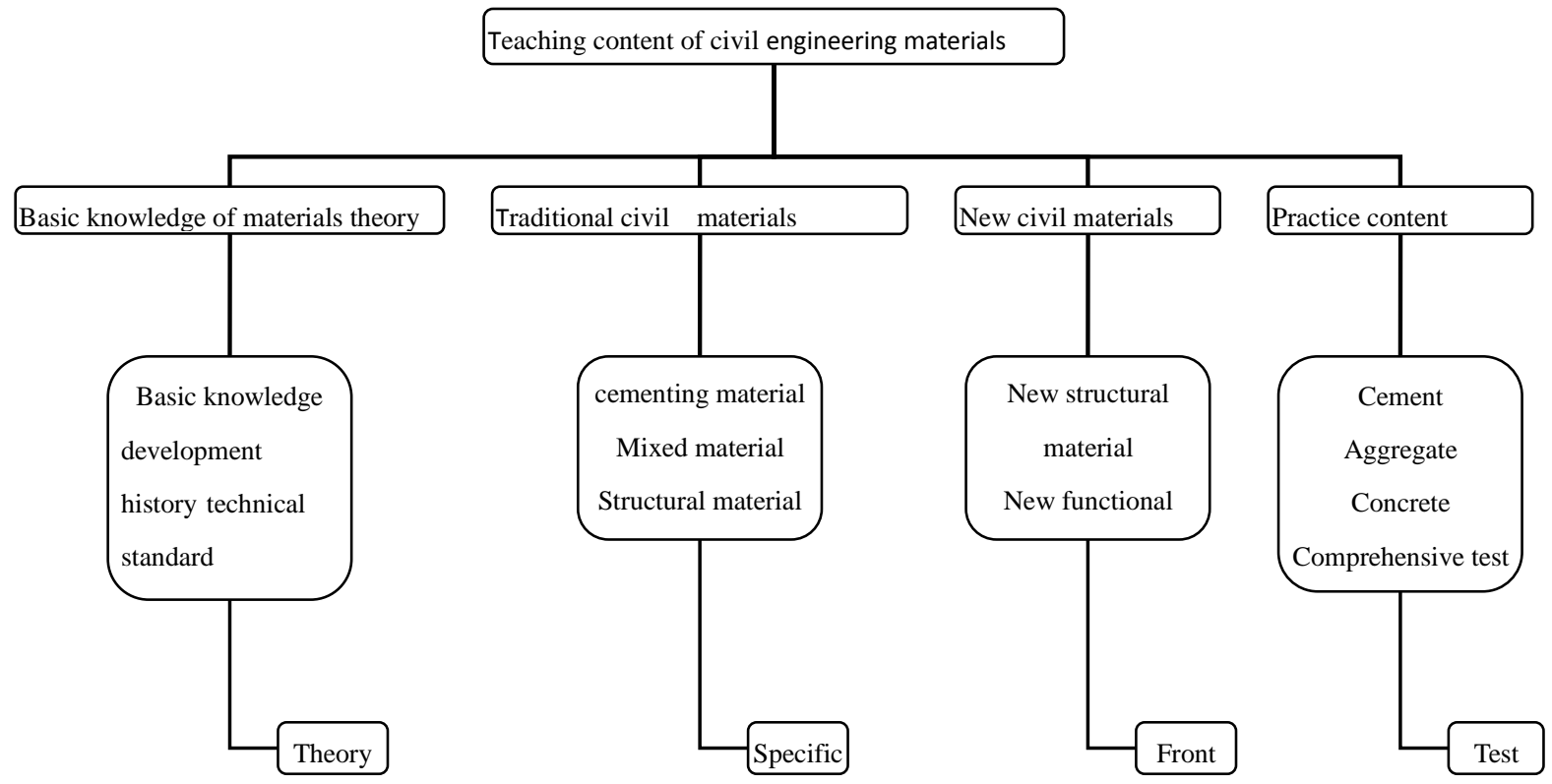

Figure 1: teaching content of civil engineering materials

After the course content is divided into blocks, students of learning content have a preliminary understanding and the four modules are not isolated, In learning is the basis of the first module, learning the second module application of specific materials, interspersed with the fourth module, confirm the theory content of the second module, find out the limitation of material application, introducing the knowledge of the third module, in the teaching process, the four modules cross learning to confirm and complement each other, to cultivate students' logical thinking ability. The seemingly unrelated different materials through the theory, experiment and the leading edge.

\section{The innovation of teaching methods}

Because of civil engineering materials course content in direct contact and logical difference, using the traditional teaching methods can not afford students learning interest, The whole course learning effect is poor, also can't cultivate students' interest in learning, American psychologist Bruner said: the best learning motivation is the students' intrinsic interest ${ }^{[2]}$. Students have interest, can stimulate learning motivation, produce learning drive, a drive can produce the desire for knowledge, produce a spark to produce innovative thinking, will have the innovation, according to the overall environment of the student and school characteristics of learning, In innovative teaching methods to take a total of teachers and students, theoretical practice, a new network of classroom.

\subsection{Teachers and students together to teach classroom content}

The purpose of classroom teaching is to arouse students' enthusiasm, teachers and students are divided into two parts, one, teachers teach theoretical knowledge, two, students talk about the application of materials, engineering examples. Teachers lecture by classes, each class of students under the control of the 30-40. For the first time, the teacher introduces the engineering example, construction accidents in material or in engineering process due to quality problems caused by improper use to enable, students can produce a visual impact, attract the attention of students, leave a deep impression, then introduce the course of civil engineering materials of the learning content, the content is divided into four modules, each module teachers use multimedia, animation, video, physical education theoretical knowledge first, require students to find the relevant knowledge of 
each module in the project application or engineering accident, the next time the before teacher teaching, students tell the search project case, and then analyze the reason, this learning method, can inspire each student's study enthusiasm and creation of thinking. In the classroom, the first student to set up a learning group, each group of 5-6 team members. Before class all the students communicate in new network, and then 2 team members to summarize the speech, make ppt courseware and explain in classroom. Students explain close to the students, students are also easy to accept, there are a lot of innovative point of view, greatly improve the enthusiasm of students learning, achieved good teaching results.

\subsection{The theoretical practice of the classroom}

For section of experimental teaching, such as cement contents chapter teachers teach in the laboratory, in the laboratory teacher can teach the theory of knowledge, while the test operation. Before the content, remove cement sample, allow students to observe the color, touch it, feel it, the students observe it, then ask questions, such as how cement produce, how much is the fineness? Method for observing real objects with problem learning can attract students attention, cause students to think. Then the teacher taught module theory of learning, after learning the theoretical study, the students begin testing, theory and Practice are close combination. Through the theory and practice of the classroom, of students in the test room then hands trial, close combination of theory and practice, can make students more intuitive understanding of the performance of the materials for the future work to lay a solid foundation. In the laboratory class, teachers can bring innovative experiments to allow students to participate in, teacher guides the students. Require students to access the relevant information, find their own sense of the test subject, independent design and study, and give full play to students' innovative consciousness, train students' logical thinking ability and professional sensitivity, cultivate and improve students' ability to innovate.

\subsection{Building a new network classroom}

Our country architectural engineering design reference international advanced practice, introduced the whole life design requirements, the state has formulated corresponding construction standard and durable resistance design, the design of important engineering is also emphasized by the emphasis on the design of durability. The quality and life span of the building are determined by the rationality and the quality of the civil engineering materials which are chosen; reinforced concrete, steel and so on are the most commonly used structural raw materials, in the actual construction process according to the materials of construction performance needs further processing shape, so the construction process whether according to the properties of the materials processing also affects the quality of the buildings and the life ${ }^{[3]}$. These content and requirements in the current teaching materials can not be reflected, and therefore can not cause the attention of students. In the process of teaching use the network platform of the school's excellent courses, add related information and task requirements, each student must find related material new norms and new standards, new engineering accidents, on the network platform communicate. In order to further implement Education information ten-year development planning(2011-2020), promote depth of integration of information technology and education, explore the micro lesson in the classroom teaching and teaching innovation in the application of effective patterns and methods, Micro class with a clear goal, short time teaching. Teacher focus on the a knowledge (key and difficult doubts) micro teaching video and uploaded to the network platform, give the students a demonstration teaching, and then give each student release task, let the students produce micro class lectures, uploaded to the network platform, we observe and learn, students micro course around the new materials, engineering examples described, to expand 
the field of vision, open-minded, improve student's logical thinking ability and innovative consciousness. Use the convenience of communication software, teachers and students set up micro channel group, timely exchange, everyone must speak in micro channel group, ask questions, timely communication, and provides each group takes turns to record on Wednesday night, find new ideas and solve new problems. Through the micro letter exchange also increases the teachers and students emotion, the micro channel group for academic exchange activities by students welcome.

\section{The examination method of innovation}

The innovation of the teaching content and teaching method and corresponding assessment methods were also the provisions of innovation, in order to encourage students to participate in teachers and students teaching class and network platform class, the traditional common result and experiment results and test results evaluation model was improved to establish a comprehensive system of evaluation mechanism. Students must have a solid theoretical foundation, also more important is students need to be able to keep up with the needs of the development of the times, cultivating good logical thinking ability and innovative consciousness and innovative ability, can be in an impregnable position in the fierce social competition. The course of evaluation as shown in Figure 2.

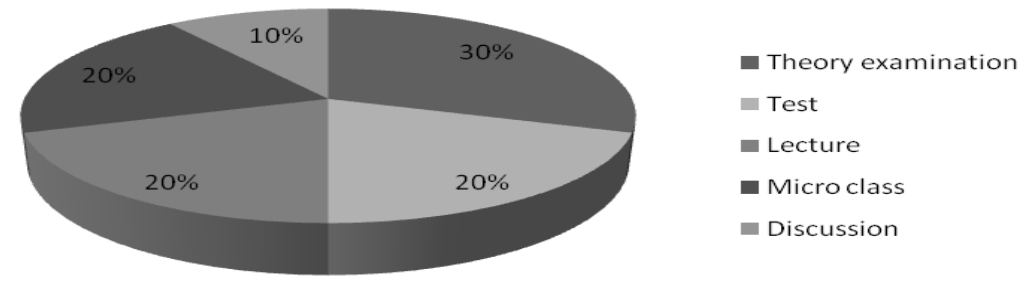

Table 2, course evaluation index

\section{Summary}

College students should not stick to the professional basic knowledge, they must have the innovation consciousness and innovation ability, civil engineering materials as the civil engineering specialized basic course to conform to the trend of the times, to keep pace with the needs of social development, according to the teaching content of the course were to explore innovative teaching, after nearly three years of teaching feedback, the overall student learning attitude have significantly improved, active learning positive significantly increased, in materials research project students is gradually increasing, innovative consciousness and innovative ability of the students have significantly improved. In the development of the times, innovation is endless, the innovative teaching of civil engineering materials course will gradually improve and improve.

Acknowledgements: Henan Province Department of Education Science and Technology Research Key Project, THE Project Number: 16A430019

\section{References}

[1]XIE Zhen-guo, Discussion of Introduction lesson in Teaching of Civil Engineering Materials [J]. Journal of Architectural Education in Insitutions of Higher Learning. 2009,18 (3).78-80

[2]Wang Qing. Teaching strategies under Constructivism [J].The Science Education Article Collects. 2008(02):26. [3]AN Ming-zhe, WU Xuan, PAN Yu. The teaching reform of Civil Engineering Material [J]. Journal of Architectural Education in Insitutions of Higher Learning.2006,15(2).89-92 